Published as: Kellens, W., Vanneuville, W., Verfaillie, E., Meire, E., Deckers, P., De Maeyer, P. (2013). Flood risk management in Flanders: past developments and future challenges. Water Resources Management, 27(10): 3585-3606.

\title{
FLOOD RISK MANAGEMENT IN FLANDERS: PAST DEVELOPMENTS AND FUTURE CHALLENGES
} \author{
Pieter Deckers ${ }^{6}$, Philippe De Maeyer ${ }^{7}$ \\ ${ }^{1,5,7}$ Ghent University \\ Department of Geography \\ Krijgslaan 281, S8 (WE12) \\ B-9000 Gent, Belgium \\ ${ }^{2}$ Geo Solutions nv \\ Veldkant 33B \\ B-2550 Kontich, Belgium \\ ${ }^{3}$ European Environment Agency \\ Kongens Nytorv 6 \\ DK-1050 København, Denmark \\ ${ }^{4}$ Havenbedrijf Gent agh \\ John Kennedylaan 32, Haven 3000 A \\ B-9042 Gent, Belgium \\ ${ }^{6}$ Flanders Hydraulics Research \\ Berchemlei 115 \\ B-2400 Borgerhout, Belgium \\ ${ }^{1}$ Corresponding author \\ email: wim.kellens@ugent.be \\ tel: +3292644696 \\ fax: +3292644985
}

Wim Kellens ${ }^{1,2}$, Wouter Vanneuville ${ }^{3}$, Els Verfaillie ${ }^{4}$, Ellen Meire ${ }^{5}$, 


\begin{abstract}
This paper presents the state of the art of flood risk management in Flanders, a low-lying region in the northern part of Belgium which is vulnerable to flooding. Possible flood hazard sources are not only the many rivers which pass through the Flemish inland, but also the North Sea, which is sensitive to the predicted sea level rise and which can affect large parts of the Flemish coastal area. Due to the expected increase in flood risks in the $21^{\text {st }}$ century, the Flemish government has changed its flood management strategy from a flood control approach to a risk-based approach. Instead of focusing on protection against a certain water level, the objective now is to assure protection against the consequences of a flood, while considering its probability.

In the first part, attention is given to the reasoning and functioning of the risk-based approach. Recent improvements to the approach are discussed, as well as the GIS-implementation of the entire model. The functioning of the approach is subsequently demonstrated in two case studies. The second part of the paper discusses future challenges for the flood risk management in Flanders. The driving force behind these challenges is the European Directive on the assessment and management of flood risks, which entered into force in 2007. The Flemish implementation of the directive is discussed and situated in the European landscape. Finally, attention is given to the communication of flood risks to the general public, since the "availability" of flood risk management plans is among the requirements of the EU Floods Directive.
\end{abstract}

\title{
Key words
}

flood risk management, GIS, EU Floods Directive, risk communication 


\section{Introduction}

Flanders is the low-lying northern part of Belgium, which geographically consists of a coastal basin plain that borders the North Sea in the north-west and a central plain that is characterized by a dense river network (cf. Figure 1). Most rivers are tributaries of the Scheldt, except for the Meuse (on the Belgian-Dutch border) and the Yser (in the west of Flanders). While the topography is relatively flat in the coastal basin and the northern part of Flanders, moderate valley slopes exist in the south of the region. Due to its high level of urbanization (average population density exceeds 460 inhabitants $/ \mathrm{km}^{2}$ ) and its dense river network, Flanders is fairly sensitive to flood hazards. During heavy rainfall or long-lasting rainy weather, parts of Flanders can be flooded by overflow of river embankments (Deckers et al. 2010; Broekx et al. 2011).

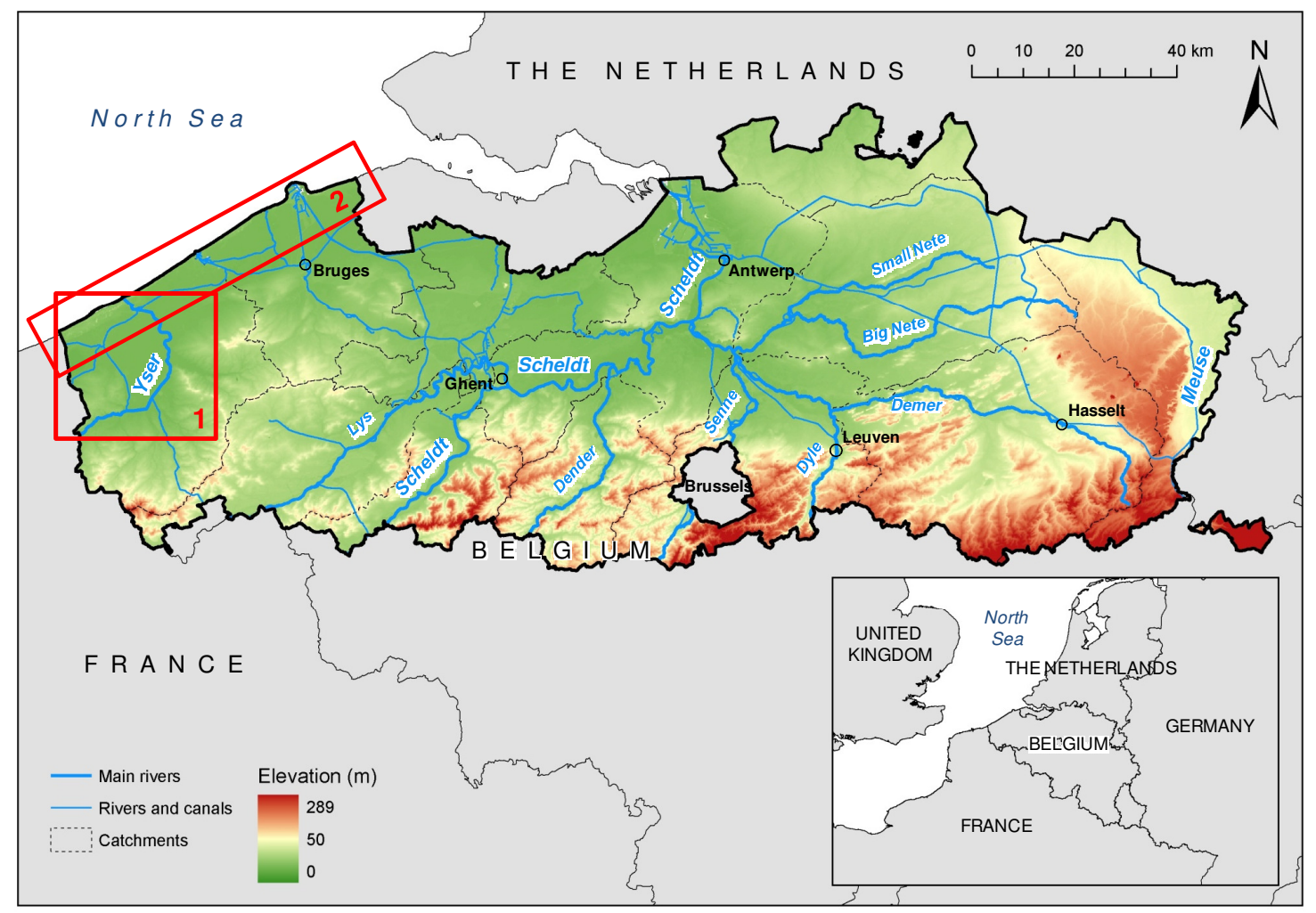

Figure 1 Location of the Flemish main rivers, smaller rivers, canals, catchments and topography; the two rectangles show the location of the case studies that are discussed in this article.

Other flood risks are related to storm winds above the North Sea, which can result in storm surges along the coastline and tidal waves rolling upstream on the Scheldt river, especially when the wind comes from a north-westerly or northerly direction. Examples are the storms of 1953 and 1976 which caused significant flood damage on the Belgian coast and along the Scheldt river (cf. Figure 1). These floods gave rise to an increased public awareness of the flood risk and initiated the so-called Sigma plan (in which "S" stands for Scheldt) in the early 1980s. Originated as a "flood control approach", the Sigma plan traced out a tidal storm surge barrier downstream Antwerp, a general heightening of the Scheldt river embankments and the construction of a number of controlled flood areas. 
Eventually, the storm surge barrier was never constructed since it could not be economically justified (Broekx et al. 2011). However, due to sea level rise and economic developments, it is generally assumed that flood risks will increase significantly in the 21 ${ }^{\text {st }}$ century (Kundzewicz et al. 2010; de Moel and Aerts 2011). The Flemish government responded to this prognosis by shifting from the "flood control approach" to a "risk-based approach" (Vanneuville et al. 2003). As the name suggests, the risk-based approach puts a strong emphasis on flood risk, which is defined as flood damage that occurs or will be exceeded with a certain probability in a certain time period (e.g., one year) (Merz et al. 2010). The movement from a flood control approach to risk-based approach yielded a focal shift from protection against a certain water level to a protection against the damage caused by the water (Johnson and Priest 2008). In practice, the risk-based approach led to an actualised Sigma plan in which flood safety is prioritized, though with nature restoration and the economic importance of the river (e.g., the harbour of Antwerp) as important parameters. In order to achieve this, controlled flooding zones, reduced tidal areas and wetlands are being installed to store abundant river water. In addition, dike enforcements and storm walls will protect urbanised areas from flooding (Broekx et al. 2011).

Initially, the implementation of a risk-based approach implied two objectives in Flanders. The first objective yielded the development of a uniform method which allowed to compare risks geographically or over time (e.g., impact of infrastructure works). Alternatives are ex ante compared to evaluate cost-efficiency and prioritize them. The second objective consisted of defining the necessary data and software for executing the risk calculations. A third objective was added in 2007, when the European Union enforced the Floods Directive (EU, 2007). The goal of this directive is to establish a framework for the assessment and management of flood risk in Europe, emphasizing both the frequency and magnitude of a flood as well as its consequences (de Moel et al. 2009).

This paper provides an overview of the state of the art of flood risk management in Flanders. Focus is given to the most significant types of floods in Flanders, being river flooding and coastal flooding. The first part "past developments" describes the risk-based approach in detail, together with some recent additions to the methodology and the GIS implementation of the model. The paper subsequently exemplifies several aspects of the risk-based approach with two case studies (one river case and one coastal case). The second part "future challenges" discusses the implementation of the European Floods Directive in Flanders' flood risk management and compares the Flemish situation with other European countries. The paper ends with a discussion on flood risk communication.

\section{Past developments}

\subsection{A risk-based approach}

The Flemish risk-based approach finds its origins in the early 2000s as a cooperation between Flanders Hydraulics Research (Flemish Government) and Department of Geography (Ghent University). It adopts a general definition for flood risk as the combination of the probability of a flood event with its (negative) consequences or losses (Füssel and Klein 2006; Smith and Petley 2009). While a substantial body of international literature provides evidence of extensive expertise in the field of damage estimation, experts and academics disagree about the methods and models to be applied. Jonkman et al. (2008a) identify three elements of dispute, which are discussed hereafter: (i) damage definition, (ii) damage appraisal and (iii) scale of analysis.

Previous literature has defined flood damages in numerous ways. Common distinctions are between direct and indirect damage, and between tangible and intangible damage. However, interpretations and delineations of what is considered a direct and indirect impact differ (Jonkman et al. 2008a). In Flanders, the distinction between direct and indirect damage is used to indicate whether flood impacts 
are first-order (they occur at the time of flooding) or second-order (they occur after the flood). As such, direct/indirect comprises a time shift in damage. Geographical distinction between damage inside and outside the flooded area is designated by the terms internal and external damage. Initial focus of the Flemish risk-based approach lied on internal tangible damage assessment, both direct and indirect (e.g., production losses, clean-up costs). Soon, the inclusion of casualty calculations (intangible damage) was added to the model (Vanneuville et al. 2003). Although models have been suggested (see Merz et al. 2010) to valuate indirect, external damages (such as production losses in companies outside the flooded area), they have been found difficult to apply, due to reasons of limited data availability and a complex economic network (Rodrigues et al. 2002; Deckers et al. 2010). Since data uniformity is one of the key objectives of the Flemish risk approach, indirect external costs are currently not considered. Up till now, intangible costs such as health effects and losses to cultural heritage are also not considered in the approach. As these impacts are requested in the EU Floods Directive (EU, 2007), it will be a challenge to incorporate them in the near future (cf. Section 3).

Barredo (2007; 2009) and Jonkman et al. (2008a) further indicate that various perspectives exist regarding damage appraisal. While some authors (e.g., Merz et al. 2010) prefer to use depreciated values, others (e.g., Vrisou van Eck et al. 1999; Vanneuville et al. 2003; Penning-Rowsell et al. 2005a) have chosen to use replacement values. Choosing between depreciated or replacement values depends on the definition of risk: macro-economic versus financial risk. Merz et al. (2010) advocate the use of depreciated values in risk management, which are suitable to calculate macro-economic risks. Replacement values on the contrary, are more appropriate to calculate financial risks. The advantage of calculating macro-economic risks is its accuracy, on condition that sufficient information is available, which is at the same time a significant disadvantage. Although replacement values may imply simplification and overestimation of the actual risk, they are generally easier to access and process. The Flemish risk-based approach applies replacement values since they better allow to meet the method's objective of data uniformity. Finally, the chosen scale of analysis may lead to variations in the risk methodology. Since Flanders is a relatively small region, all calculations can be performed at micro- to meso-level, being $5 \times 5$ m grids.

Figure 2 depicts the flow chart of the Flemish risk-based approach, which consists of three calculation phases: (i) flood hazard calculations (probability and physical extent), (ii) vulnerability and damage calculations and (iii) flood risk calculations. The following sections describe each of these phases in more detail. Given the scope of this article, particular attention is given to the second and the third phase. 


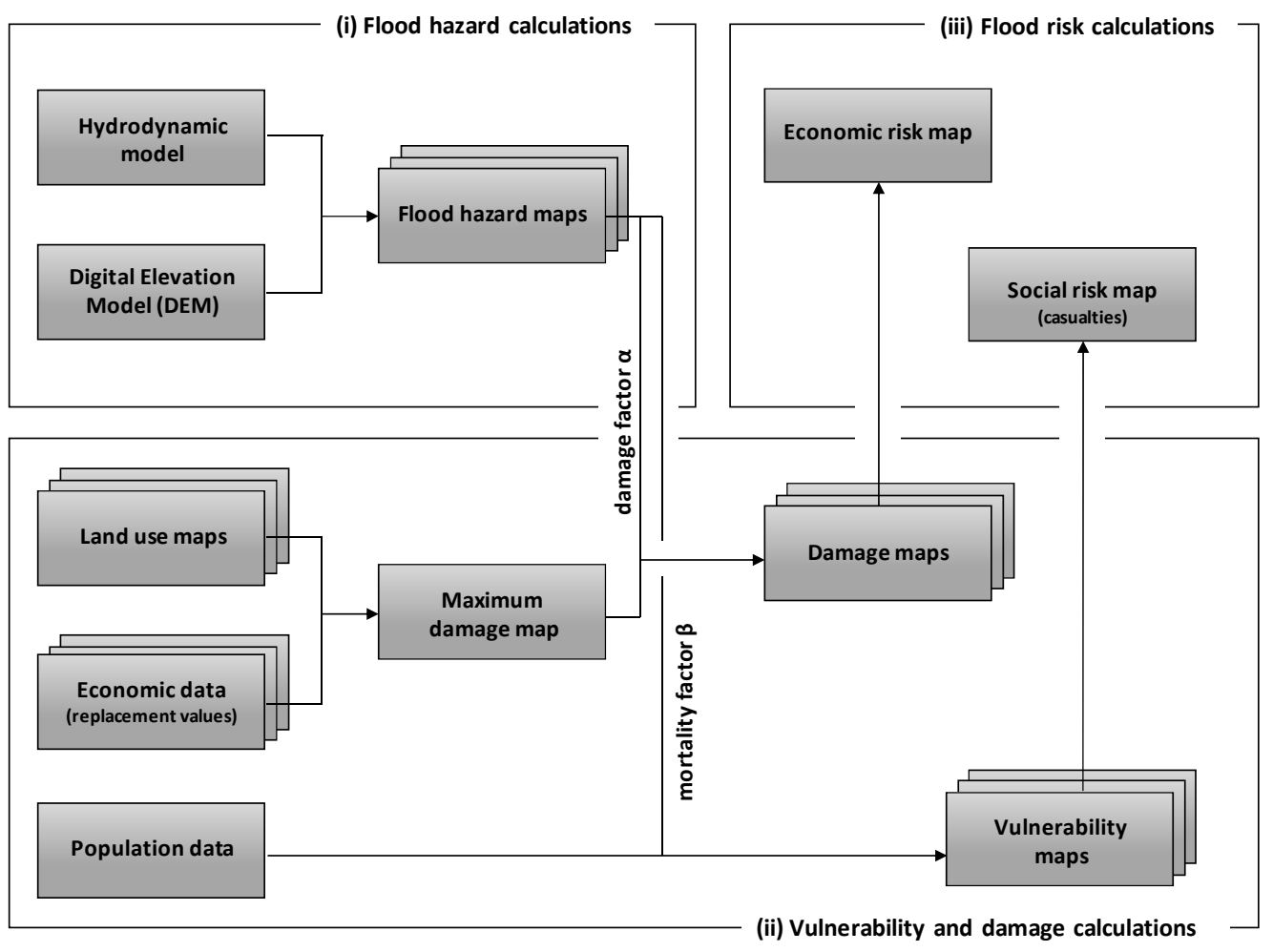

Figure 2 Flow chart of the Flemish risk-based approach

\subsubsection{Flood hazard calculations}

The first phase in the risk-based approach involves the computation of a set of flood hazard maps, for which two groups of data models are employed. A first group concerns various hydrologic and hydrodynamic models, with specific usages for river or coastal flood modeling. The Flemish river flood modeling is mainly based on a quasi two-dimensional approach in which the floodplains are modeled as a network of fictitious river branches and spills with the rivers. Hydrographs are being used to identify potential flooding areas in a river basin. These hydrographs are derived for each subbasin on the basis of an extreme value analysis applied to a long-term time series of rainfall-runoff discharges (see Willems et al. (2002) for a comprehensive overview of the hydrologic models for water courses in Flanders). Coastal flood modeling is based on probability calculations of (extreme) storm surges as well as coastal plain flood modeling. The response of the coastal defence system is simulated as a combination of wave propagation towards the coastal defence, beach erosion, wave overtopping, structural failure of the revetment, erosion of the core and finally breach growth (see Verwaest et al. (2008) for an overview of these models).

A second group of data input comprises a high-resolution digital elevation model, referred to as "DHM Vlaanderen", with a standard vertical accuracy of $7 \mathrm{~cm}$ on hard surfaces and short grass (see www.agiv.be for more information). The generated hazard maps each represent the physical extent of a flood with its particular return period (probability). Higher water levels correspond to larger return periods of occurrence. The flood maps not only show maximum water level in each grid cell, but also indicate the spatial extent of a specific inundation. Other parameters, such as flow velocity and the rate at which the water rises are also mapped. 


\subsubsection{Vulnerability and damage calculations}

The second phase forms the heart of the risk-based approach. Using various geographic and socioeconomic data, damage (i.e. economic damage) and vulnerability (i.e. casualties) maps are computed.

Since there is no information on the damage behaviour of each object and/or because such a detailed assessment would require a huge effort, it is not possible to assess the maximum damage for each single object (Merz et al. 2010). Therefore, elements at risk are pooled into classes, and the damage assessment is performed equally for each of these classes. In the Flemish risk methodology, groups of elements are mainly based on land use classification. Using different data sets with land use information, a number of land use classes are defined, for example urban area, industrial area, infrastructure, crop land, pastures, etc (cf. Table 1). These classes are further divided in various subclasses, for example 16 different classes are defined for industrial buildings (e.g., chemical industry, food industry, metallurgical industry, etc.). For residential housing, distinction is made between the value of the building (fixed asset) and the value of the contents (moveable items, e.g., furniture). Numerous line and point elements (such as roads, railroads, hospitals, telecommunication towers, etc.) are added afterwards. Replacement values are subsequently assigned to these groups of elements.

Table 1 Overview of categories and subcategories which are considered in damage calculations

\begin{tabular}{|c|c|c|c|c|c|}
\hline $\begin{array}{l}\text { Categories } \\
\text { (sub-) }\end{array}$ & $\begin{array}{l}\text { Meas. } \\
\text { Unit }\end{array}$ & $\begin{array}{l}\text { Maximum } \\
\text { Direct } \\
\text { Damage } \\
\text { (in Euros) }\end{array}$ & $\begin{array}{l}\text { Categories } \\
\text { (sub-) }\end{array}$ & $\begin{array}{l}\text { Meas. } \\
\text { Unit }\end{array}$ & $\begin{array}{l}\text { Maximum } \\
\text { Direct } \\
\text { Damage } \\
\text { (in Euros) }\end{array}$ \\
\hline Roads & & & Airport & $\mathrm{m}^{2}$ & 100 \\
\hline Highways & $\mathrm{m}$ & 1650 & Recreational Area & $\mathrm{m}^{2}$ & 0.03 \\
\hline Major roads & $\mathrm{m}$ & 850 & Cropland & $\mathrm{m}^{2}$ & $0.3-2.1$ \\
\hline Roads for regional traffic & $\mathrm{m}$ & 750 & $\begin{array}{l}\text { Pasture } \\
\text { Special buildings and }\end{array}$ & $\mathrm{m}^{2}$ & 0,08 \\
\hline Connecting roads & $\mathrm{m}$ & 700 & constructions & & \\
\hline Access Roads & $\mathrm{m}$ & 300 & Hospital, Rest Home & $\mathrm{m}^{2}$ & 1400 \\
\hline Railways & & & City Hall, School & $\mathrm{m}^{2}$ & 1400 \\
\hline Singular Railways & $\mathrm{m}$ & 625 & Fire, Police Station, Prison & $\mathrm{m}^{2}$ & 1560 \\
\hline Multiple Railways & $\mathrm{m}$ & 7500 & Church, Abbey, Monastery & $\mathrm{m}^{2}$ & 1400 \\
\hline Urban area & & & Museum & $\mathrm{m}^{2}$ & 1560 \\
\hline Buildings (*) & $\mathrm{m}^{2}$ & $500-2400$ & Shopping centre & $\mathrm{m}^{2}$ & 5300 \\
\hline Furniture & $\mathrm{m}^{2}$ & $30 \%$ of $(*)$ & Castle & $\mathrm{m}^{2}$ & 19500 \\
\hline Open Space & $\mathrm{m}^{2}$ & 1 & Gas Station & object & 900000 \\
\hline Industrial area & & & Wind Mill & object & 687500 \\
\hline Buildings & $\mathrm{m}^{2}$ & $100-680$ & Wind Turbine & object & 712000 \\
\hline Open space & $\mathrm{m}^{2}$ & 100 & Cars & object & 4500 \\
\hline
\end{tabular}

Next, damage functions are employed to determine the expected damage for each return period. Damage functions relate expected damage for the respective group of elements at risk to characteristics of the inundation (Pistrika and Jonkman 2010). In general, distinction is made between empirical damage functions (based on historical data) and expert damage functions (based on expert judgment). While the former is a popular method in the UK and the Netherlands, the latter method is preferred in Germany and France (de Moel and Aerts 2011). Currently, Flanders employs expert damage functions, adopted from Vrisou van Eck et al. (1999), Van der Sande (2001) and PenningRowsell et al. (2010). In the future, however, it is planned to move towards empirical damage functions using damage information from recent flood events. Figure 3 depicts several damage functions which are currently in use in the Flemish risk approach. The graphs represent the expected damage (as damage factor $\alpha$ in percentages) for three land use classes (roads, industry and residential housing) and goods (furniture) as a function of the water depth. Notice the "flat" stroke between 1 and 
$2 \mathrm{~m}$ for furniture. This should be interpreted as "no matter if the water depth is $1 \mathrm{~m}$ or $2 \mathrm{~m}$, furniture will be lost, so no extra damage is expected with increasing water depth". However, once the water depth exceeds $2 \mathrm{~m}$, furniture of the first floor can be damaged as well, so the damage function increases again. All damage factors are equal to 1 if the water depth amounts to $5 \mathrm{~m}$ or more.

Finally, the maximum damage map is combined with the set of flood maps which results in a set of damage maps for each return period. The expected damage $D_{\text {exp }}$ can be mathematically described as follows:

$$
D_{\text {exp }}=\sum_{\text {entities }} \alpha * D_{\max } * N
$$

Where: $\quad D_{\max }: \quad$ maximal damage or potential damage in a certain land occupation

$\alpha$ : coefficient expressing the relation between water depth and damage (cf. Figure 3)

$N: \quad$ number of entities

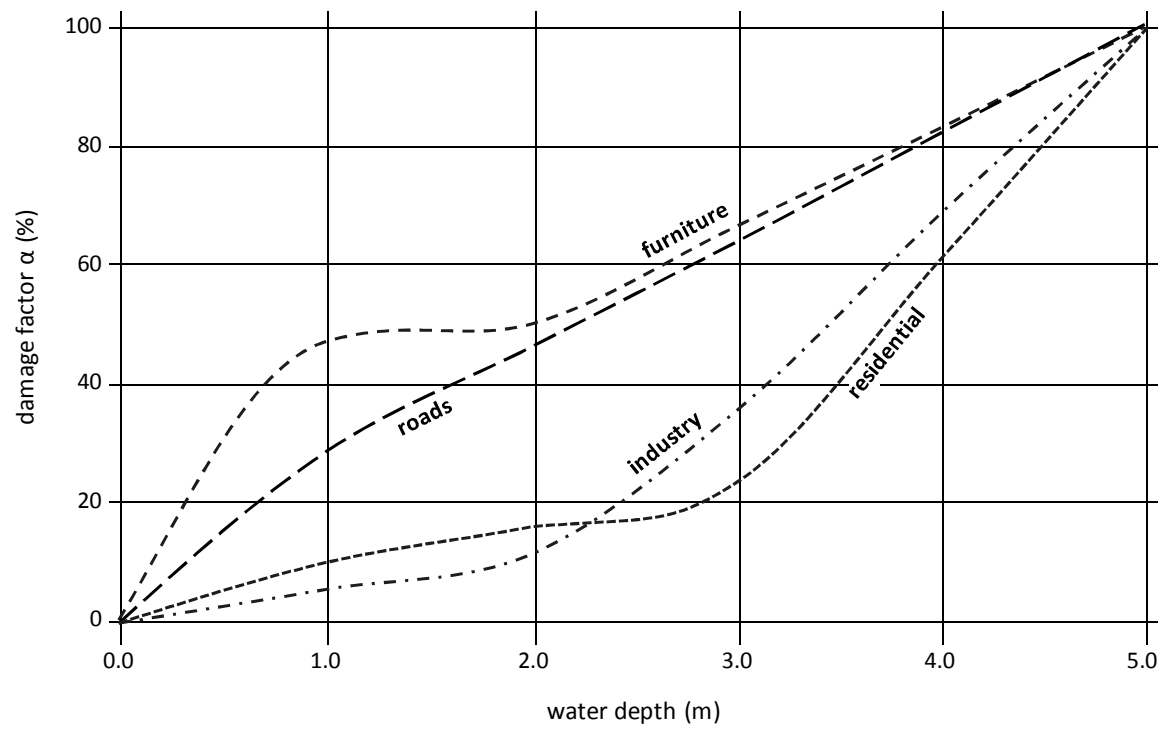

Figure 3 Damage functions: expected damage for different land use classes (roads, industry and residential housing) and goods (furniture) as a function of water depth (Deckers et al. 2010)

While overflow of dikes, embankments or seawalls is the main cause of flooding in Flanders (Broekx et al. 2011), other flood causes are also examined, such as geotechnical failure or dike breaching. Due to high flow velocity in the vicinity of a breach, damage to built-up areas may be much larger than in an overflow scenario. In general, it is assumed that flow velocity generates an additional damage on top of the present damage calculations based purely on water depth. Based on findings of Vrisou van Eck et al. (1999), new damage functions were developed for levels of water depth in combination with flow velocity (Verwaest et al. 2008). These functions define a flow velocity of $3 \mathrm{~m} / \mathrm{s}$ and a water depth of $0.5 \mathrm{~m}$ as thresholds for buildings to collapse. Thus if both thresholds are exceeded, a maximum damage is applied. On the Belgian coast, dune breaching is also considered.

The second phase also involves the calculation of vulnerability maps which represent the number of expected casualties among the population exposed to the flood hazard. 
People are especially vulnerable to rapidly rising and/or flowing water and debris flows (PenningRowsell et al. 2005b; Jonkman and Penning-Rowsell 2008). In the Flemish risk-based approach, no monetary value is attributed to human life. Casualties are instead calculated in persons $/ \mathrm{m}^{2}$. Three steps are generally defined in these calculations (Jonkman 2007). The first step involves the assessment of physical effects associated with the flood, including the dispersion of the effects and the extent of the exposed area. Relevant flood characteristics for casualty calculations are water depth, the rate at which the flood water rises, and the flow velocity. In the second step, the number of people exposed to the hazard is determined. Jonkman et al. (2008b) has argued that in large-scale applications with high population numbers, the number of people exposed can safely be approximated by the registered population in the area (the number of inhabitants). On the one hand, however, this number might be underestimated when large numbers of tourists visit the area regularly, for example in coastal areas. Tourists who spend the night on the Belgian coast are therefore also considered in the Flemish risk methodology. Estimations of the tourist number are based on statistics about the number of occupied second residences (Gunst et al. 2008). On the other hand, the number of people exposed might be overestimated as well, for example due to timely evacuation of inhabitants. Yet, evacuation effects are not considered at present since their impact on the casualty risk is small when comparing different scenarios, but also because of the large uncertainties associated with this process (particularly in urbanized areas where thousands of people would be evacuated for several kilometers). In the third step, the casualty number amongst the exposed population is estimated using so-called mortality functions. Analogous to the damage functions, mortality functions depict the expected percentage of casualties given a particular flood characteristic, such as water depth, rise velocity, and flow velocity (discharge). For water depth and rise velocity, values were taken from the empirical research work of Vrisou van Eck et al. (1999). According to their findings, the number of casualties grows exponentially with water depth $d$ :

$$
\begin{aligned}
f_{d}=e^{(1.16 d-7.3)} & \text { with } \quad f_{d} \leq 1 \\
\text { Where: } f_{d}: & \text { mortality factor in function of water depth } \\
d: & \text { water depth in meter } \\
e: & \text { mathematical constant }= \pm 2.718
\end{aligned}
$$

The mortality factor $f_{d}$ reaches 1 with a water depth of $6.3 \mathrm{~m}$ or more. The expected number of casualties further increases linearly with rise velocity $r$ :

$$
\begin{aligned}
f_{r}=0.37 r-0.11 & \text { with } \quad 0.3 \leq r<3.0 \\
\text { Where: } f_{r}: & \text { mortality factor in function of rise velocity } \\
r: & \text { rate at which water rises }(\mathrm{m} / \mathrm{h})
\end{aligned}
$$

The condition in equation 3 signifies that if $r<0.3 \mathrm{~m} / \mathrm{h}$, no casualties are expected as a result of rise velocity. However, if $r>3.0 \mathrm{~m} / \mathrm{h}, 100 \%$ mortality is expected among the people exposed. With regard to flow velocity, useful parameters were found in empirical research on building resistance. Vrisou Van Eck et al. (1999) showed that walls will collapse if the product of flow velocity and water depth exceeds $1,5 \mathrm{~m}^{3} / \mathrm{m} / \mathrm{s}$. These conditions correspond to a mortality of $100 \%$.

\subsubsection{Risk calculations}

In the third and final phase, the damage and vulnerability maps are combined into economic flood risk maps, which express the mean annual damage per surface per year, and into social flood risk maps, which express the mean annual expected victims. As mentioned before, risk combines both the 
probability of a flood event (return period) and its consequences (expected losses). Computing the risk for any flood event implies a summation of all damages for the different return periods under consideration, while taking into account the damage related to statistically more frequent events (in order to avoid damage to be counted multiple times). The risk $\mathrm{R}$ is mathematically defined as follows:

$$
R=\sum_{i=1}^{n} \frac{1}{i}\left(D_{i}-D_{i-1}\right)
$$

Where: $\quad D_{\mathrm{i}}$ : damage related to a flood event with a return period of $\mathrm{i}$ time (e.g., year)

$n: \quad$ the highest return period which is considered

\subsection{Recent improvements}

The Flemish risk-based approach has been recently extended with a number of improvements. Among the most important are (i) the inclusion of time dependency for agriculture, and (ii) a revision of the land use maps including point elements.

In earlier versions of the risk-based approach, the estimated damage of the agricultural land use categories (pastures and croplands) was entirely based on water depth. However, as De Nocker et al. (2007) indicate, the amount of agricultural damage is more dependent on the moment of a flood (i.e., a flood in the winter will cause less damage than a flood in the summer just before harvesting) than on the water depth (Morris et al. 2008; Posthumus et al. 2009). Therefore, new damage functions for croplands and pastures were developed. Based on the life cycle (seeding, growing, harvesting) and the relative occurrence of the most common Flemish crops (De Nocker et al. 2007), the degree of occupation of the croplands was calculated for the different months and for different regions in Flanders. This degree of occupation is implemented in the risk methodology so the estimated flood damage to agriculture now differs from season to season.

A second improvement concerns the use of more detailed land use information. In the original methodology, land use classification was based on CORINE Land Cover maps $\left(100 \times 100 \mathrm{~m}^{2}\right)$ and the

Small Scale Land Use Map of Flanders $\left(20 \times 20 \mathrm{~m}^{2}\right)$; both are based on classifications of satellite images and particularly useful for small scale applications. Information about the location (as a XYcoordinate) of objects, such as special buildings and constructions, was subsequently added to the land use data. This approach appeared useful for damage and risk calculations on river catchment level (de Moel and Aerts 2011). In recent years, however, the need to perform risk calculations at higher detail levels (e.g., along small unnavigable brooks) has increased. New data sets meet this need. At the catchment level, a vector-based data (Biological Valuation Map of Flanders) set is now used to define land use classes. In addition, high-detailed cadastral information is applied to represent the exact location of the residential and industrial buildings. Moreover, special buildings like hospitals, schools, etc. (cf. Table 1) are no longer represented as points with XY-coordinates but are now represented by their surface area based on small-scale topographical data.

\subsection{GIS implementation}

As Jonkman et al. (2008a) recognize, geographical information is the key binding element in flood risk modelling. In a GIS environment, various data sources related to topography, land use, economic activities, population, etc. can be overlaid and analysed. A GIS is thus without doubt the best aid to implement the risk-based approach so that risk calculations can be operationalized. 
The Flemish risk-based methodology was first implemented using the model builder of the general raster-GIS IDRISI. However, this implementation posed some disadvantages, such as (i) userunfriendly interface, (ii) time-consuming model start-up, (iii) non-effective data management and (iv) long calculation times (as a result of the disadvantages (ii) to (iii)). It followed that the development of a user-friendly, tailor-made, effective tool for flood risk assessment was felt necessary. Built on Microsoft.NET technology and programmed in C\#.NET, LATIS filled in these needs. Using the computing capacity and built-in standard modules of IDRISI, LATIS allows to calculate damage and risk maps in Flanders in an easy (the user only has to take care of input flood hazard maps), uniform (same method and data for the whole territory of Flanders) and reproducible way (data management system records the set of input data).

LATIS is currently being employed by researchers at Flanders Hydraulics Research and the Flemish Environment Agency (VMM) as a decision support tool for policy makers and flood risk managers while evaluating different plausible flood risk reduction scenarios and in the technical reports substantiating the reporting under the Floods Directive. LATIS is also applied in the two case studies which are described hereafter.

\subsection{Case studies}

This section presents two case studies. A first case study involves scenario calculations in the catchment of the Yser river. A second case study focuses on casualty and damage calculations along the Belgian coast. Whereas the river case demonstrates the latest improvements to the risk-based approach (being the inclusion of time dependency for agriculture and revised land use maps), the coastal case shows the economic (material damage) and social (casualties) losses due to overflow of seawalls and dike breaching. Figure 1 shows the location of both study areas in Flanders (study area 1 refers to the Yser case study, study area 2 to the Belgian coast study).

\subsubsection{Flood risks in the Yser catchment}

The Yser finds its origin in the north of France (close to Kassel), enters Belgium near Houtkerque and discharges into the North Sea in the town Nieuwpoort (cf. Figure 4). The Yser measures $78 \mathrm{~km}$ and carries down water from a $1100 \mathrm{~km}^{2}$ large basin area. About two thirds of its length and basin area are located in the Belgian province West Flanders. On Belgian territory, the Yser is a typical low-land river with a very small drop: only $4 \mathrm{~m}$ over $45 \mathrm{~km}$ or $0.08 \mathrm{~m} / \mathrm{km}$. About $35 \%$ of the river basin comprises polders (croplands and pasture). The municipalities of Diksmuide (approx. 16,000 inhabitants) and Nieuwpoort (approx. 11,000 inhabitants) make up the most important urban areas along the Yser.

A weir in Nieuwpoort closes the Yser from the North Sea tide fluctuations, which makes river discharge only possible at low tide (Heylen 1997). In case of high water levels on the Yser, water can be discharged through the Lo canal and the canal Nieuwpoort-Dunkerque (indicated by "Canal N-D" in Figure 4). In the past, the Yser has frequently caused extensive floods in the western part of Flanders. In case of heavy and prolonged rainfall, the Yser's water level can increase rapidly, especially when the weir in Nieuwpoort is closed due to high sea tide. Discharge through the Lo canal may then not be sufficient (Heylen 1997). Recent severe floods have occurred in the winter of 2002/2003 and 2010 (D'Haeseleer and Vanneuville 2006; CIW 2011). Figure 4 depicts the recently flooded areas as dashed polygons. 

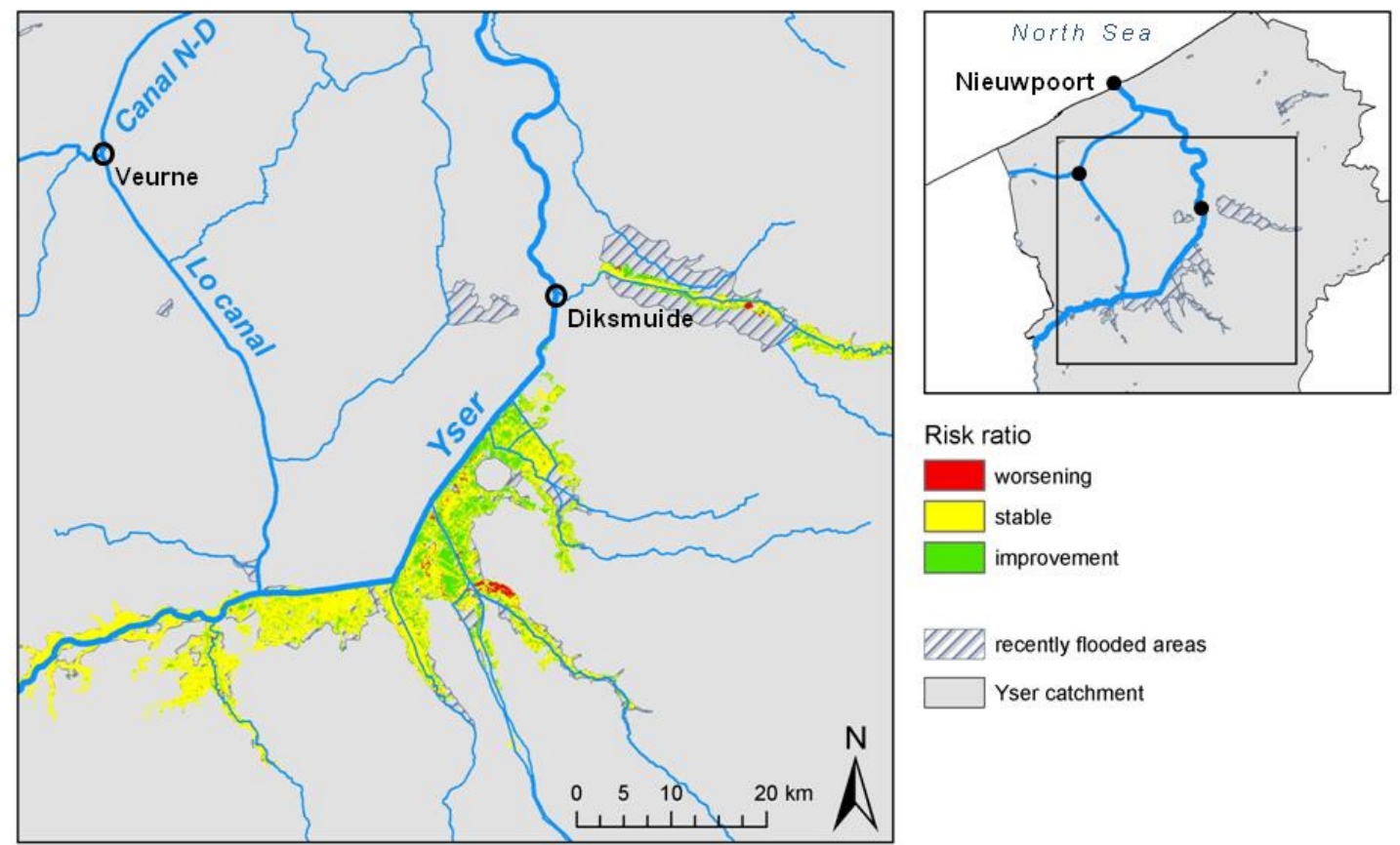

Risk ratio

worsening

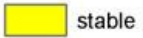

$\square$ stable
improvement

QDI/ recently flooded areas

Yser catchment

Figure 4 Recently flooded areas and risk ratio in the Yser catchment. The risk ratio depicts the change in flood risk between the reference scenario and the building of pumps on the Yser in Nieuwpoort (see text for more information).

In 2006, Flanders Hydraulics Research was commissioned by W\&Z (the Agency of Waterways and Sea Canal) to examine the effects of the installation of pumps along the Yser (in Nieuwpoort), in Veurne and adjustments along the Lo canal. Apart from studying the hydrological and hydraulic impacts of each of these scenarios on the Yser discharge, attention was also given to the effects on flood damage and risk calculations (D'Haeseleer and Vanneuville 2006). Four scenarios were considered (cf. Table 2):

- reference scenario (denoted as "reference"): this is the current situation;

- raising of the maximum water level in the Lo canal from $3.50 \mathrm{~m}$ TAW to $3.70 \mathrm{~m}$ TAW (denoted as "Lo canal");

building of emergency pumps in Veurne (denoted as "Pumps_V"), which makes permanent water discharge in the Lo canal possible in case of high water levels on the Yser;

building of pumps on the Yser in Nieuwpoort (denoted as "Pumps_N"), so that water discharge from the Yser can be assured, even if the weir is closed during high sea tide.

Flood risks were calculated from a set of damage maps with different return periods $(1,2,5,10,25$, 50 and 100 years). Table 2 shows the economic risks for each of the scenarios per summer half year (1 April - 1 October) and per winter half year (1 October - 1 April) for different land use classes. The "ratio"-value depicts the risk change as compared to the reference scenario. Apparently, only the scenario with the construction of pumps in Nieuwpoort results in a relatively significant risk reduction of $8.4 \%$ in summer and $6.2 \%$ in winter. Figure 4 shows the geographical location of this risk reduction. Green pixels represent an improvement or reduction of the flood risk, red pixels represent a worsening of the risk. Apart from depicting the risk ratio, the map also shows that most of the flood risk is expected to occur upstream from Diksmuide along a number of tributaries of the Yser. As Table 2 indicates, these areas are mainly occupied by croplands and pastures. Both land use classes represent about $83 \%$ of the flood risk in the summer half year. However, their contribution to the total risk drops to about $21 \%$ in the winter half year. Since the summer months are crucial for crops and 
their life cycle (cf. Section 2.2), the losses caused by flooded cropland are much larger in summer than in winter (factor 6). For pasture, the differences are even larger. This can be explained by the cutting regime of hay, which amounts to about five cutting turns between April and October, but none in the winter months. Consequently, flooded pasture does not entail economic damage during this season (De Nocker et al. 2007).

Noteworthy is that the same set of flood hazard maps were used in both summer and winter scenario. An equal chance of flooding is thus assumed between summer and winter flooding. In Belgium, average precipitation numbers are effectively similar between the summer and winter half year $(411.3$ $\mathrm{mm}$ versus $441.1 \mathrm{~mm}$ respectively), though analysis of time series over 100 years showed that there is a trend towards more extreme rain showers in the winter (Ntegeka and Willems 2008). In addition, the winter implies a higher probability of storm at sea which subsequently limits the discharge possibilities of the Yser.

Table 2 Economic risk (in thousands of Euros per half year) in summer half year and in winter half year

\begin{tabular}{lllllllll}
\hline & \multicolumn{2}{c}{ Reference } & \multicolumn{2}{c}{ Lo canal } & \multicolumn{2}{c}{ Pumps_V } & \multicolumn{2}{c}{ Pumps_N } \\
\hline Land use & Summer & Winter & Summer & Winter & Summer & Winter & Summer & Winter \\
\hline Roads and railways & 45.0 & 45.0 & 43.5 & 43.5 & 44.5 & 44.5 & 40.0 & 40.0 \\
Urban area (buildings) & 3.2 & 3.2 & 3.1 & 3.1 & 3.1 & 3.1 & 3.0 & 3.0 \\
Urban area (open space) & 11.5 & 11.5 & 11.4 & 11.4 & 11.4 & 11.4 & 10.8 & 10.8 \\
Industrial area (buildings) & 0.0 & 0.0 & 0.0 & 0.0 & 0.0 & 0.0 & 0.0 & 0.0 \\
Industrial area (open space) & 17.5 & 17.5 & 17.0 & 17.0 & 17.5 & 17.5 & 16.0 & 16.0 \\
Cropland & 257.5 & 42.5 & 250.0 & 41.0 & 256.0 & 42.5 & 233.0 & 38.5 \\
Pasture & 510.0 & 0.0 & 503.5 & 0.0 & 507.5 & 0.0 & 466.0 & 0.0 \\
Wind turbine & 74.0 & 74.0 & 73.0 & 73.0 & 74.0 & 74.0 & 73.0 & 73.0 \\
\hline Total & 918.6 & 193.6 & 901.4 & 188.9 & 914.0 & 193.0 & 841.8 & 181.3 \\
\hline Ratio $(\%)$ & 100 & 100 & 98.1 & 97.9 & 99.5 & 99.7 & 91.6 & 93.8 \\
\hline
\end{tabular}

Table 3 shows the flood risk estimations for the Yser catchment based on two different land use maps, namely the "old" land use map based on small-scale information (CORINE Land Cover and the Small Scale Land Use Map of Flanders), and the "new" land use map based on high-detailed vector information (Biological Valuation Map of Flanders and cadastral data; cf. Section 2.2). Average annual damage values were used for agriculture.

Just as in the previous risk calculations (cf. Table 2), the installation of pumps in Nieuwpoort is denoted as the overall financially most advantageous scenario. The risk improvement amounts to about $8 \%$ with the "new" land use map and over $10 \%$ with the "old" land use map. The largest differences between both land use maps are observed for the roads and railways. The reduction of 75 $\%$ of the flood risk with the new land use maps can be attributed to a different road classification. Whereas 30 types of roads were distinguished in the old land use data (i.e. TOP50v), the number of types was limited to five in the new land use data (i.e. NAVStreet). Although the reclassification of road types was based on a "best fit" for Flanders, disparities are possible in areas with an overrepresentation of a certain road type. Next, an increase in flood risk for cropland is observed in the new land use data. This seems complementary with the decrease in flood risk for open space. The high detail-level of the cadastral information allows to better differentiate between open space area and cropland and pasture. The remaining classes do not differ significantly between both data sets. All together, there is a flood risk reduction of about $20 \%$ with the new land use data, compared to the old data. 
Table 3 Economic risk (in thousands of Euros per year) according to the old and the new land use data set

\begin{tabular}{lllllllll}
\hline & \multicolumn{2}{c}{ Reference } & \multicolumn{2}{c}{ Lo canal } & \multicolumn{2}{c}{ Pumps_V } & \multicolumn{2}{c}{ Pumps_N } \\
\hline Land use & Old & New & Old & New & Old & New & Old & New \\
\hline Roads and railways & 338 & 90 & 332 & 87 & 337 & 89 & 319 & 80 \\
Urban area (buildings) & 8.5 & 6.3 & 8.4 & 6.1 & 8.5 & 6.2 & 7.9 & 5.9 \\
Urban area (open space) & 32.3 & 22.9 & 32.1 & 22.7 & 32.1 & 22.8 & 26.9 & 21.6 \\
Industrial area (buildings) & 0.0 & 0.0 & 0.0 & 0.0 & 0.0 & 0.0 & 0.0 & 0.0 \\
Industrial area (open space) & 75.2 & 34.5 & 74.6 & 34.2 & 74.7 & 34.5 & 23.4 & 31.7 \\
Cropland & 264 & 297 & 259 & 288 & 263 & 295 & 246 & 269 \\
Pasture & 502 & 510 & 495 & 504 & 500 & 508 & 458 & 466 \\
Wind turbine & 148 & 148 & 146 & 146 & 148 & 148 & 146 & 146 \\
\hline Total & 1368 & 1108 & 1348 & 1088 & 1362 & 1103 & 1227 & 1020 \\
\hline Ratio (\%) & 100 & 100 & 98.5 & 98.2 & 99.6 & 99.5 & 89.7 & 92.1 \\
\hline
\end{tabular}

Two conclusions can be drawn from this case study. First, the scenario with the installation of pumps in Nieuwpoort has shown to be the scenario with the largest flood risk reduction seen over the entire area. Obviously, other aspects - e.g., environmental, social and technical constraints - will have to be considered in the decision-making process. To this end, techniques such as a multi-criteria analysis can be employed (Costa et al. 2004). Second, the case study has demonstrated the importance of employing risk values in a relative way. Methodological improvements such as the inclusion of time dependency for agriculture and the revision of land use maps can have major effects on absolute flood risk values, though the case study showed minor changes at the relative level. Absolute values should always be used with the proper circumspect.

\subsubsection{Impact of storm surges on the Belgian coast}

The Belgian coast is located on the Southern Bight of the North Sea and is characterized by an artificial linear coastline, which alternates dunes, harbours and urbanization. The relatively small coastal area is the setting for a number of widely divergent human activities, resulting in a high concentration as well as a complex spatial intertwining of functions, such as tourism, industry, fisheries and agriculture (Belpaeme and Konings 2004). Overall, over 200,000 people reside in the coastal area. During summer holidays, this number is doubled by residential tourists (Gunst et al. 2008).

The Belgian coast is protected against flooding from the sea by natural and artificial defence elements. Natural elements are dunes, sandbanks and beaches which form a protective belt of a few hundred meters to several kilometres wide and up to 30 meters high. In addition, several places particularly the harbours and the urbanized areas - are protected by artificial coastal defence techniques, such as groins and seawalls. As such, more than half the Belgian coastline is protected by one or several manmade reinforcements. Without these artificial reinforcements, major parts of coastal area and the low-lying polders would easily inundate, even by a yearly storm.

Recent studies have been commenced to improve the coastal safety, thereby considering the effects of the climate change and the subsequent sea level rise for the North Sea region up to the year 2050. Together, these studies form the Master Plan of Coastal Safety (MPCS; Agency for Maritime and Coastal Services). Analogous to river floods, risk calculations are employed to measure the possible effects of a severe storm surge on the coastal area (Mertens et al. 2010). Whereas the return period of the Flemish rivers are in the order of 1 to 100 years, it is relevant to take much smaller probabilities into account with regard to coastal flood risks. However, relatively little reliable scientific knowledge exists about such super storm surges. Flood risk calculations in the frame of the MPCS are therefore 
performed with an alternative, probabilistic risk formula that is based on the weighted average of a number of storm events (Verwaest et al. 2008).

As described in Section 2.1.2, a number of context-specific aspects are considered in the computation of coastal flood risk calculations (both damage and casualties), such as overflow, (dike) breaching and flow velocities. Table 4 gives an overview of the output of these calculations for the three major coastal areas (cf. Figure 5 or Figure 6 for their location). With regard to the specific location of the flood "source", four types are considered:

- type A: on the seawall as a result of water overflow and/or breaches;

- type B: in the flooded interior as a result of water overflow and/or breaches in the seawall near coastal municipalities and villages;

- type C: in the flooded interior as a result of water overflow and/or breaches in harbours (only relevant for the municipalities of Nieuwpoort, Blankenberge and Zeebrugge);

- type D: in the flooded interior as a result of water overflow and/or breaches in the city of Oostende (on the seawall or in the harbour).

Table 4 Damage and casualty risks for the Belgian coast

\begin{tabular}{l|ccccc|ccccc} 
& \multicolumn{4}{|c}{ Economic risks (in 100,000 Euros per year) } & \multicolumn{5}{c}{ Casualty risks (in numbers per year) } \\
& $\mathbf{A}$ & $\mathbf{B}$ & $\mathbf{C}$ & $\mathbf{D}$ & Totals & A & B & C & D & Totals \\
\hline West coast & 0.03 & 0.00 & 12.76 & - & 12.79 & 0.03 & 0.00 & 0.17 & - & 0.20 \\
& $0.20 \%$ & $0.03 \%$ & $99.77 \%$ & - & $100 \%$ & $16.74 \%$ & $0.06 \%$ & $83.19 \%$ & - & $100 \%$ \\
Middle coast & 0.28 & 1.79 & 0.00 & 162.11 & 164.19 & 0.93 & 0.00 & 0.00 & 0.90 & 1.83 \\
& $0.17 \%$ & $1.09 \%$ & $0.00 \%$ & $98.73 \%$ & $100 \%$ & $50.64 \%$ & $0.12 \%$ & $0.00 \%$ & $49.23 \%$ & $100 \%$ \\
East coast & 0.01 & 0.09 & 73.84 & - & 73.95 & 0.03 & 0.00 & 0.61 & - & 0.64 \\
& $0.02 \%$ & $0.12 \%$ & $99.86 \%$ & - & $100 \%$ & $4.85 \%$ & $0.00 \%$ & $95.15 \%$ & - & $100 \%$ \\
\hline Totals & 0.32 & 1.89 & 86.61 & 162.11 & 250.93 & 0.99 & 0.00 & 0.77 & 0.90 & 2.67 \\
& $0.13 \%$ & $0.75 \%$ & $34.51 \%$ & $64.60 \%$ & $100 \%$ & $37.13 \%$ & $0.09 \%$ & $29.04 \%$ & $33.74 \%$ & $100 \%$
\end{tabular}

Percentages are to be read horizontally.

From Table 4, it follows that the main flood sources for economic damage are Oostende (type D) and the harbours (type C). Together, these types represent over $99 \%$ of the total economic risk that is expected in case of a severe storm surge. Expressed in absolute numbers, coastal flooding may cause a total economic damage of 25 million Euros per year in the coastal area. The Middle coast clearly runs the largest risk with about 16 billion Euros, in which Oostende has an extremely large share (98.7\%). The East coast and the West coast respectively account for 7.4 and 1.3 million Euros to the annual economic risk. The map in Figure 5 depicts the areas along the coastline that are most vulnerable to economic damage (that is, the total economic damage in these areas exceeds $90 \%$ of the total economic damage on the Belgian coast). Most vulnerable areas are clearly the agglomerations of Oostende/Bredene, Middelkerke (which is flooded from the harbour of Nieuwpoort), Blankenberge and Zeebrugge. 


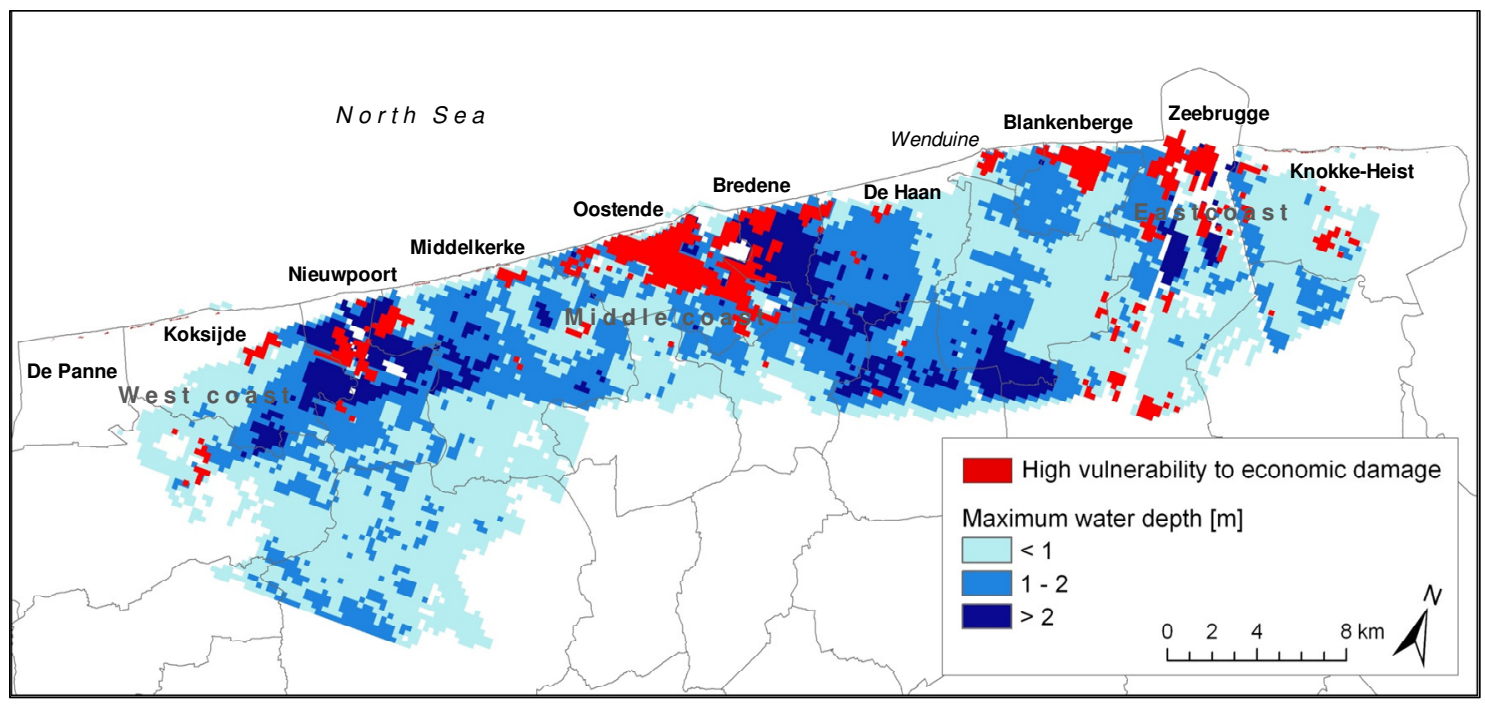

Figure 5 Indication of areas with high vulnerability to economic damage on the Belgian coast

A slightly different image is found for the casualty risks (cf. Table 4). Three flood source types are nearly equally important, namely flooding on the seawall due to overflow or dike breaching (type A; $37.1 \%$ ), flooding in harbours (type C; 29\%) and flooding in Oostende (type D; 33.7\%). The large share by flood source type A is not surprising, given that the population density is prominent in the many apartment buildings that are located directly on the seawall. Analogous to Figure 5, Figure 6 shows the areas in the coastal area that are most vulnerable to casualties (that is, the total number of casualties in these areas exceeds $90 \%$ of the total number of casualties on the Belgian coast). Notice the small line along the coastline which represents flood type A. The map further indicates that particularly the centres of Oostende and Bredene and the villages of Wenduine and Middelkerke account for the highest casualty numbers.

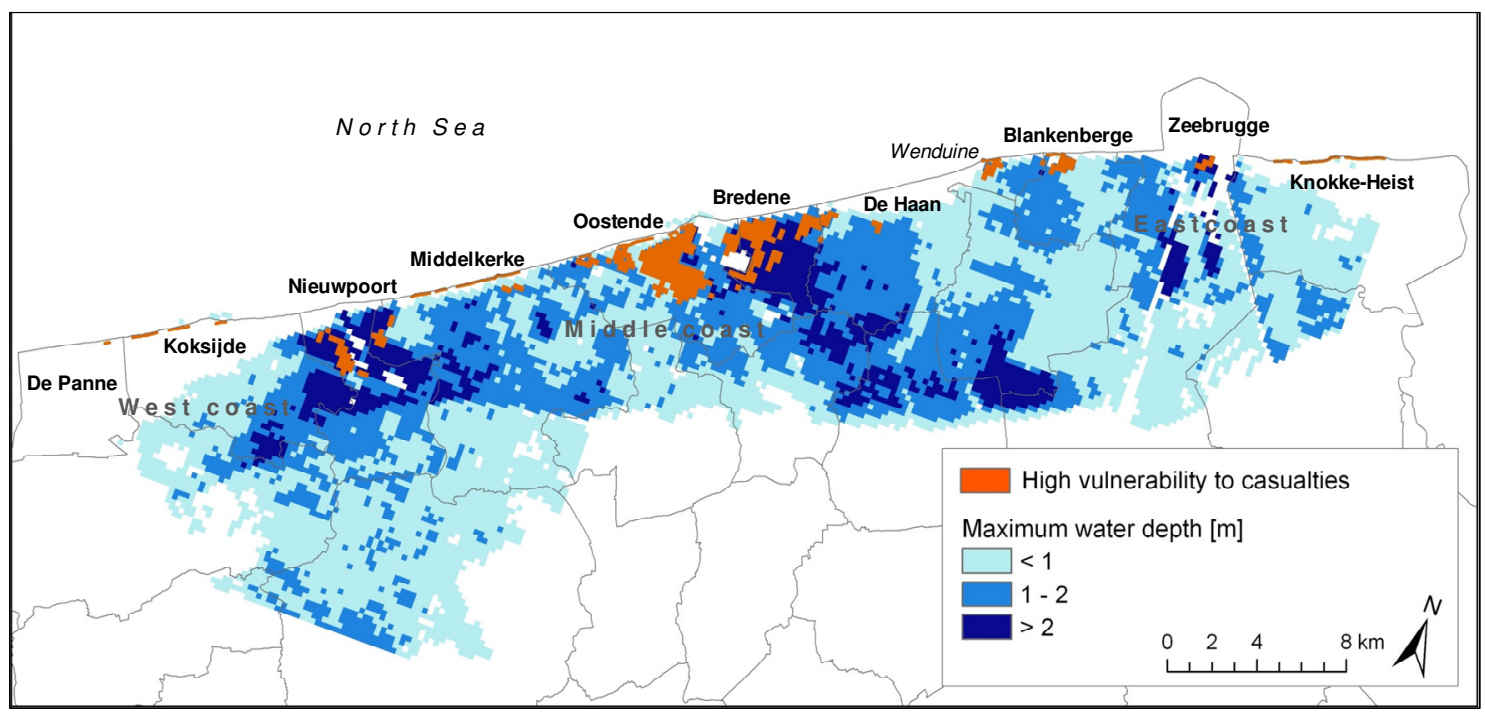

Figure 6 Indication of areas with high vulnerability to casualties on the Belgian coast 
To conclude, it is clear from the above case study that some parts of the Belgian coast are more vulnerable to flooding than others. The risk calculations showed that in case of a major storm, particularly Oostende may suffer from large economic damages as well as casualties. Other vulnerable locations are the harbours (Nieuwpoort, Blankenberge and Zeebrugge; economic damage) and Wenduine (casualties). Based on these - and more in-depth - findings, the Master Plan of Coastal Safety has concluded that about one third of the Belgian coast is insufficiently protected against a 1,000-year flood. These locations will be prioritized in the future for additional defence measures, such as beach nourishment and dike heightening (Mertens 2010).

\section{Future challenges}

\subsection{European Floods Directive}

The European Floods Directive (EU, 2007) aims to reduce and manage the flood related adverse consequences for human health, the environment, cultural heritage and economic activities. It therefore imposes on the European Member States to produce flood risk management plans by the end of 2015. These plans should be preceded by a comprehensive flood risk assessment as well as flood hazard maps and flood risk maps. After 2015, the flood risk management plans have to be updated every six years. The Floods Directive can be regarded as a complement to the European Water Framework Directive (EU, 2000), which had a primary focus on the development of river basin management plans to achieve a good ecological and chemical status.

Within the Floods Directive, flood risk management should concentrate on prevention, protection and preparedness. These components correspond with two of the four components of the emergency management cycle (FEMA 2003), being prevention-mitigation (where protection can be seen as an equivalent of mitigation) and preparedness. Preventive actions to reduce flood probability can be spatial planning measures (e.g. no new human settlements within flood prone areas) or the building of embankments as coastal defense measures. Preparedness can include risk communication for awareness raising, emergency planning and early warning. The two other components of this emergency management cycle are response (e.g. crisis communication) and recovery (e.g. insurance payments for rebuilding). Although the directive not literally requires that flood risk management plans focus on response, the directive demands that results are made available to the public. Moreover, active involvement of interested parties should be encouraged by the Member States when producing, reviewing and updating the flood risk management plans. This can be interpreted as a demand for more communication towards stakeholders (e.g. Hagemeier-Klose and Wagner 2009a; van Alphen et al. 2009) and a demand for more flood risk management participation from citizens (e.g., White et al. 2010).

\subsubsection{Implementation of the Floods Directive in Flanders}

Flanders faces two main challenges regarding the implementation of the Floods Directive: (i) the incorporation and quantification of intangible damage effects (health effects, environmental effects, cultural heritage); and (ii) the inclusion of other than river and sea-borne types of floods.

The current Flemish risk-based approach focuses on the tangible losses from flooding, being economic damage and casualty numbers. However, the Floods Directive requires that attention is also given to the assessment of health effects, environmental effects and effects on cultural heritage of flooding. These aspects have been taken into account for a social cost-benefit analysis in the Flemish Sigma plan (Broekx et al. 2011), but not in a quantitative way. The measurement of these intangible 
effects will be a first challenge for Flanders. As Mostert and Junier (2009) already indicated, there exists very little experience about expressing these effects as quantitative measures. Research on health effects due to floods focuses mainly on the consequences of the overflow of sewage networks. These overflows result in an increase of bacteria, which can be assessed quantitatively (e.g., Karrasch et al. 2009; ten Veldhuis et al. 2010). Social studies on health effects are generally assessed qualitatively by questionnaires (e.g., Tapsell et al. 2002; Tunstall et al. 2006). Flood related environmental effects are not well studied, except for many regional environmental impact assessments (Mostert and Junier 2009). Floods imply changes in water quality due to higher concentrations of heavy metals, biogenic elements and pesticides, resulting in a disturbance of vegetation cover and fauna (Istomina et al. 2005). Flood effects on cultural heritage are in a way comparable to economic damage to buildings. However, damaged historic buildings or cultural heritage sites will never be comparable to the original situation. The first challenge is thus twofold: firstly, the quantification of the effects has to be achieved; secondly, these quantified effects have to be combined with the tangible losses from flooding. A possible way of combining these effects is a multi-criteria analysis. On-going projects, such as the FloodResilientCity (FRC) project, are making attempts towards an integrated approach of all effects (see www.floodresiliencity.eu).

The second challenge of the flood-approach is the incorporation of other types of floods than currently is the case. The Floods Directive (art. 2) defines a flood as "a temporary covering by water of land not normally covered by water. This includes floods from rivers, mountain torrents, Mediterranean ephemeral water courses, and floods from the sea in coastal areas, and may exclude floods from sewerage systems." The current Flemish risk-based approach only takes into account river and seaborne floods, while floods due to torrential rainfall or high ground water levels are also relevant (e.g., Kreibich et al. 2009). Since hydrodynamic models are not (yet) available for these flood types, a pragmatic method will be first applied to incorporate these floods. A useful document in this regard will be the map with recently flooded areas in Flanders, which is constantly updated by the Flemish authorities.

\subsubsection{The Flemish situation in the European landscape}

Compared with other EU countries, Flanders decided not to execute a preliminary flood risk assessment but to make the flood hazard and flood risk maps immediately. This strategy is also partly pursued by a number of neighbouring countries. Flanders particularly distinguishes itself from other European regions in the sense that it is integrating Floods Directive and Water Framework Directive as from the first generation of river basin management plans (2009). The deadline for the flood risk management plans (Floods Directive) and the second generation of river basin management plans (Water Framework Directive) is the same (2015). As such, Flanders is preparing one integrated plan suitable for both directives.

\subsection{Towards active flood risk communication?}

As mentioned earlier, the EU Floods Directive obliges the European countries to make their flood risk management plans available and accessible to the general public. While the Directive thus promotes passive communication, several researchers have interpreted this obligation as a first step towards active risk communication to the public (de Moel et al. 2009; Hagemeier-Klose and Wagner 2009b).

Communicating flood risks to the public in a refined and understandable way may be crucial for a number of reasons (Rowan 1991): (i) building trust in the communicator, (ii) raising awareness (e.g., of a potential flood hazard), (iii) educating, (iv) reaching agreement (e.g., on a particular strategy or investment plan) and (v) motivating action (e.g., precautionary measures against flooding of 
residence). Several researchers (e.g., Correia et al. 1998; Bell and Tobin 2007; Hagemeier-Klose and Wagner 2009a) have emphasized the role of flood risk communication to strengthen people's risk awareness and to motivate the population at risk to take preventive actions and to be prepared for an emergency case. Knowledge of the people's perceptions, preferences and needs may be essential to come to an effective risk communication (e.g. Keller et al. 2006; Bell and Tobin 2007; Kellens et al. 2011).

The recent years have witnessed a remarkable growth in the number of studies that have (at least partially) considered flood risk communication, for example COMRISK (2001-2005), SafeCoast (2005-2008) and FLOODsite (2004-2009). In addition, research networks such as CRUE ERA-net (Schanze et al. 2008) and CapHaz-net (Höppner et al. in press) have emphasized the role of risk communication in the context of flood hazards. A specific group of projects (e.g., EXCIMAP, RISKCATCH) has also examined how maps can be employed to communicate flood risks to the public. Because of their visual impact, flood maps are seen as ideal instruments to inform the general public about flood hazards and flood risks and strengthen people's risk awareness (EXCIMAP 2007; Fuchs et al. 2009). Moreover, the use of flood maps is also encouraged by the EU Floods Directive as a basis for flood risk management (de Moel et al. 2009; Meyer et al. 2012).

At present, Flanders lacks a large-scale active communication program regarding flood risks. The authorities sometimes disseminate flood (risk) related information via reports and leaflets, though these are mostly limited in edition and in spatial spread. Passive communication is realized through the availability of web maps with flood information. For river floods, web maps exist for both navigable and non-navigable waterways, providing actual information on water levels, water discharge and precipitation (cf. www.waterstanden.be and www.overstromingsvoorspeller.be). For several river basins, a 48 hour forecast can be consulted. As for coastal floods, no web maps are available to the public yet. Instead, Strategic Environmental Assessment (SEA) plans can be consulted by the public. These comprehensive plans contain information on various aspects of the measures that will be taken to reduce the flood risk. In addition, the first steps towards a participatory approach are being taken. This approach involves the organization of several workshops in which different aspects of the flood risk management planning are explained to the participants. To date, these participants are mainly professionals, but it is intended to involve the public in the future as well.

Flanders faces a number of challenges regarding active flood risk communication. First, it will need to further stimulate people's interest in flood related information, so that people are "open" to it. Then, the communication will have to be delivered in a way that is understood. Keller et al. (2006) mention the problem for people of correctly interpreting risks with low probabilities but high consequences, such as flood disasters. Slovic (1987) showed that people care more about the number of people that is exposed to threats and the familiarity they have with the threat (experience), than paying attention to statistical probabilities. The communication will further have to address the heterogeneity of the public (Martens et al. 2009), foster mutual understanding and mediate between different views (Höppner et al. in press). It will also be a challenge to deal with uncertainty which is inherent to risk assessment (Mostert and Junier 2009; White et al. 2010). Finally, the communication will have to be specific rather than generic, which means that communication should be adjusted to the specific needs of the people (Renn 2005).

\section{Conclusion}

This paper presented the state of the art of the Flemish risk-based approach regarding flood hazards. It showed that the current methodology is elaborate in the context of economic damage assessment and casualty calculations. Recent adjustments with regard to agriculture and land use have further 
improved the methodology. Two case studies demonstrated the usefulness of the methodology to support the decision-making process in choosing the best measures (cf. Yser study) or focus on the most vulnerable parts of a region (cf. coastal study).

Yet, this article also demonstrated that there is still considerable work to do. Two main challenges follow from the requirements of the European Floods Directive, namely the incorporation and quantification of intangible damage effects (health effects, environmental effects and loss of cultural heritage) and the inclusion of other than river and sea-borne types of floods. The first challenge involves the development of a methodology to quantify intangible effects and to consequently combine them with tangible effects using multi-criteria analyses. The second challenge is in essence a demand for additional hydrodynamic models which are able to model other types of floods, such as pluvial and groundwater induced floods. Once these models are set, it will be a minor task to incorporate them into the risk methodology.

Although the European Floods Directive primarily focuses on the prevention-mitigation-preparedness aspects of the hazard life cycle, there exists a general call for more attention to response and recovery, as well as to flood risk communication. A clear emergency action plan for different levels of flood disasters resulting in adequate reactions of all stakeholders is crucial for an efficient response. A better recovery could be achieved by sufficient help for normalizing the situation, enough help for administrative actions that have to be taken by citizens to inform all involved refunding organizations, an efficient and quick disbursement by disaster funds and a good communication of lessons that are learned from earlier floods. Whereas the Floods Directive requires flood risk management plans to be available to the public, more active flood risk communication is suggested by several researchers. This article showed that this aspect is underexposed in Flanders, but that the first steps have been taken in that direction.

\section{Acknowledgements}

Financial support for this work was provided by Research Foundation - Flanders.

\section{References}

Barredo J (2007) Major flood disasters in Europe: 1950-2006. Natural Hazards 42:125-148

Barredo J (2009) Normalised flood losses in Europe, 1970-2006. Natural Hazards and Earth System Sciences 9:97-104

Bell HM, Tobin GA (2007) Efficient and effective? The 100-year flood in the communication and perception of flood risk. Environmental Hazards 7:302-311

Belpaeme K, Konings P (2004) De Kustatlas Vlaanderen-België. Coördinatiepunt voor Geïntegreerd Beheer van Kustgebieden.

Broekx S, Smets S, Liekens I, Bulckaen D, De Nocker L (2011) Designing a long-term flood risk management plan for the Scheldt estuary using a risk-based approach. Natural Hazards $57: 245-266$

CIW (2011) Globale evaluatie overstromingen 2010. Rapport Coördinatiecommissie Integraal Waterbeleid (CIW) (www.integraalwaterbeleid.be)

Correia FN, Fordham M, Saraiva MdG, Bernardo F (1998) Flood Hazard Assessment and Management: Interface with the Public. Water Resources Management 12:209-227

Costa CABE, da Silva PA, Correia FN (2004) Multicriteria evaluation of flood control measures: The case of Ribeira do Livramento. Water Resources Management 18:263-283

D'Haeseleer E, Vanneuville W (2006). Model 712/5: "Effecten van pompen op IJzer in Nieuwpoort en ingrepen Lokanaal". WL Reports. Antwerp, Flanders Hydraulics Research 
de Moel H, Aerts J (2011) Effect of uncertainty in land use, damage models and inundation depth on flood damage estimates. Natural Hazards 58: 407-425

de Moel H, van Alphen J, Aerts JCJH (2009) Flood maps in Europe - methods, availability and use. Natural Hazards and Earth System Sciences 9:289-301

De Nocker L, Joris I, Janssen L, Smolders R, Van Roy D, Vandecasteele B, Meiresonne L, Van der Aa B, De Vos B, De Keersmaeker L, Vandekerkhove K, Gerard M, Backx H, Van Ballear B, Van Hove D, Meire P, Van Huylenbroeck G, Bervoets K (2007). Multifunctionaliteit van overstromingsgebieden : wetenschappelijke bepaling van de impact van waterberging op natuur, bos en landbouw, VITO (by order of VMM)

Deckers P, Kellens W, Reyns J, Vanneuville W, De Maeyer P (2010) A GIS for Flood Risk Management in Flanders. Geospatial Techniques in Urban Hazard and Disaster Analysis. P. S. Showalter and Y. Lu, Springer-Verlag: 51-69

EU (2000) Directive 2000/60/EC of the European Parliament and of the Council of 23 October 2000 establishing a framework for Community action in the field of water policy (OJ L 327, 22.12.2000)

EU (2007) Directive 2007/60/EC of the European Parliament and of the Council of 23 October 2007 on the assessment and management of flood risks (OJ L 288 06.11.2007)

EXCIMAP (2007) Handbook on good practices for flood mapping in Europe. European Exchange Circle on Flood Mapping.

FEMA (2003) A Nation Prepared. Federal Emergency Management Agency Strategic Plan (20032008)

Fuchs S, Spachinger K, Dorner W, Rochman J,Serrhini K. (2009) Evaluating cartographic design in flood risk mapping. Environmental Hazards 8:52-70

Füssel HM, Klein R (2006) Climate change vulnerability assessments, an evolution of conceptual thinking. Climatic Change 75:301-329

Gunst C, Vandenbroucke L, Verhaeghe A (2008) Secondary residences in focus [in Dutch]. WestVlaanderen Werkt 3:14-21

Hagemeier-Klose M, Wagner K (2009a) Evaluation of flood hazard maps in print and web mapping services as information tools in flood risk communication. Natural Hazards and Earth System Sciences 9:563-574

Hagemeier-Klose M, Wagner K (2009b) Risk Communication and the EU-Directive for Flood Risk Management an Evaluation of Information Tools for the General Public. Wasserwirtschaft 99:24-28

Heylen J (1997) The Hydrology of the Yser Basin. Water 97:239-244

Höppner B, Bründl M, Whittle R, Buchecker M. (in press): Linking social capacities and risk communication in Europe: a gap between theory and practice? Natural Hazards. DOI: 10.1007/s11069-012-0356-5

Istomina MN, Kocharyan AG, Lebedeva IP (2005) Floods: Genesis, Socioeconomic and Environmental Impacts. Water Resources 32:349-358

Johnson CL, Priest SJ (2008) Flood risk management in England: a changing landscape of risk responsibility? International Journal of Water Resources Development 24:513-525

Jonkman SN (2007). Loss of life estimation in flood risk assessment - theory and applications, Delft University. Phd: 354

Jonkman SN, Bockarjova M, Kok M, Bernardini P (2008a) Integrated hydrodynamic and economic modelling of flood damage in the Netherlands. Ecological Economics 66:77-90

Jonkman SN, Penning-Rowsell E (2008) Human Instability in Flood Flows. Journal of the American Water Resources Association 44:1208-1218

Jonkman SN, Vrijling JK, Vrouwenvelder ACWM (2008b) Methods for the estimation of loss of life due to floods: a literature review and a proposal for a new method. Natural Hazards 46:353389

Karrasch B, Mehrens M, Link U (2009) Increased incidence of saprophytic bacteria, coliforms and E.coli following severe flooding requires risk assessment for human health: results of the River Elbe flood in August 2002. Journal of Flood Risk Management 2:16-23

Kellens W, Zaalberg R, Neutens T, Vanneuville W, De Maeyer P (2011) An Analysis of the Public Perception of Flood Risk on the Belgian Coast. Risk Analysis 7:1055-1068 
Keller C, Siegrist M, Gutscher H (2006) The role of the affect and availability heuristics in risk communication. Risk Analysis 26:631-639

Kreibich H, Thieken AH, Grunenberg H, Ullrich K, Sommer T (2009) Extent, perception and mitigation of damage due to high groundwater levels in the city of Dresden, Germany. Natural Hazards and Earth System Sciences 9:1247-1258

Kundzewicz ZW, Hirabayashi Y, Kanae S (2010) River Floods in the Changing Climate-Observations and Projections. Water Resources Management 24:2633-2646

Martens T, Garrelts H, Grunenberg H, Lange H (2009) Taking the heterogeneity of citizens into account: flood risk communication in coastal cities - a case study of Bremen. Natural Hazards and Earth System Sciences 9:1931-1940

Mertens T, Verwaest T, Delgado R, Trouw K, De Nocker L (2010). Coastal Management and Disaster Planning on the Basis of Flood Risk Calculations. Coastal Engineering 2010, Shanghai, China

Merz B, Kreibich H, Schwarze R, Thieken A (2010) Review article "Assessment of economic flood damage". Natural Hazards and Earth System Sciences 10:1697-1724

Meyer V, Kuhlicke C, Luther J, Fuchs S, Priest S, Dorner W, Serrhini K, Pardoe J, McCarthy S, Seidel J, Scheuer S, Palka G, Unnerstall H, Viavatenne C (2012) Recommendations for the user-specific enhancement of flood maps. Natural Hazards and Earth System Sciences 12:1701-1716

Morris J, Bailey AP, Lawson CS, Leeds-Harrison PB, Alsop D, Vivash R (2008) The economic dimensions of integrating flood management and agri-environment through washland creation: A case from Somerset, England. Journal of Environmental Management 88:372-381

Mostert E, Junier SJ (2009) The European flood risk directive: challenges for research. Hydrology and Earth System Sciences Discussions 6:4961-4988

Ntegeka V, Willems P (2008) Trends and multidecadal oscillations in rainfall extremes, based on a more than 100-year time series of $10 \mathrm{~min}$ rainfall intensities at Uccle, Belgium. Water Resources Research 44: W07402, doi:10.1029/2007WR006471

Penning-Rowsell E, Johnson C, Tunstall S, Tapsell S, Morris J, Chatterton J, Green C, Wilson T, Koussela K, Fernandez-Bilbao A (2005a) The benefits of flood and coastal risk management: a handbook of assessment techniques. Middlesex University Press, London, UK.

Penning-Rowsell E, Floyd P, Ramsbottom D, Surendran S (2005b) Estimating Injury and Loss of Life in Floods: A Deterministic Framework. Natural Hazards 36: 43-64

Penning-Rowsell E, Viavattene C, Pardoe J, Chatterton J, Parker DJ, Morris J (2010) The benefits of flood and coastal risk management: a handbook of assessment techniques - 2010. Flood Hazard Research Centre (FHRC): London. ISBN 978-0-9565567-0-7. VIIII, 90 pp.

Pistrika AK, Jonkman SN (2010) Damage to residential buildings due to flooding of New Orleans after hurricane Katrina. Natural Hazards 54:413-434

Posthumus H, Morris J, Hess TM, Neville D, Phillips E, Baylis A (2009) Impacts of the summer 2007 floods on agriculture in England. Journal of Flood Risk Management 2:182-189

Renn O (2005). White Paper on Risk Governance: Towards an Integrative. Geneva, Switzerland, International Risk Governance Council (IRGC): 157

Rodrigues AS, Santos MA, Santos AD, Rocha F (2002) Dam-break flood emergency management system. Water Resources Management 16:489-503

Rowan KE (1991) Goals, obstacles and strategies in risk communication: a problem-solving approach to improving communication about risks. Journal of Applied Communication Research 19:300-329

Schanze J, Hutter G, Penning-Rowsell E, Nachtnebel H-P, Meyer V, Werritty A, Harries T, Holzmann H, Jessel B, Koeniger P, Kuhlicke C, Neuhold C, Olfert A, Parker D, Schildt A (2008). Systematisation, evaluation and context conditions of structural and non-structural measures for flood risk reduction. FLOOD-ERA Joint Report

Slovic P (1987) Perception of Risk. Science 236:280-285

Smith K, Petley DN (2009) Environmental Hazards. Assessing risk and reducing disaster, London.

Tapsell SM, Penning-Rowsell EC, Tunstall SM, Wilson TL (2002) Vulnerability to flooding: health and social dimensions. Philosophical Transactions of the Royal Society of London Series aMathematical Physical and Engineering Sciences 360:1511-1525 
ten Veldhuis JAE, Clemens F, Sterk G, Berends BR (2010) Microbial risks associated with exposure to pathogens in contaminated urban flood water. Water Research 44:2910-2918

Tunstall SM, Tapsell SM, Green CH, Floyd P, George C (2006) The health effects of flooding: social research results from England and Wales. Journal of Water Health 4:365-380

van Alphen J, Martini F, Loat R, Slomp R, Passchier R (2009) Flood risk mapping in Europe, experiences and best practices. Journal of Flood Risk Management:285-292

Van der Sande CJ (2001). River flood damage assessment using IKONOS imagery. J. R. C. European Commission. Ispra, Italy, Natural Hazards Unit. VIII: 77

Vanneuville W, De Maeyer P, Maeghe K, Mostaert F (2003) Model the effects of a flood in the Dender catchment based on a risk methodology. Bulletin of the Society of Cartography 37:59-64

Verwaest T, Van der Biest K, Vanpoucke P, Reyns J, Vanderkimpen P, De Vos L, De Rouck J, Mertens T (2008) Coastal Flooding Risk Calculations for the Belgian Coast. Coastal Engineering 1-5: 4193-4201

Vrisou van Eck N, Kok M, Vrouwenvelder ACWM (1999) Standardized method for damage and casualties resulting from floods - part 2: Backgrounds (in Dutch), HKV-Lijn in Water \& TNO Bouw by order of RWS-DWW

Willems P, Vaes G, Popa D, Timbe L, Berlamont J (2002) Quasi 2D river flood modeling. In: Bousmar D, Zech Y. (eds.), River Flow 2002, 2:1253-1259

White I, Kingston R, Barker A (2010) Participatory geographic information systems and public engagement within flood risk management. Journal of Flood Risk Management 3:337-346 